DIFUSI

Volume 2, No.2 Juli 2019

ISSN 2615-2363

\title{
PENYUSUNAN PEDOMAN PENGGAJIAN KARYAWAN KOPERASI WARGA POLBAN (KWP)
}

\author{
Marwansyah $^{1}$, Tri Setyowati ${ }^{1}$, Nurlaila Fadjarwati ${ }^{1}$, Tiafahmi Angestiwi ${ }^{1}$ \\ ${ }^{1}$ UP-MKU, Politeknik Negeri Bandung \\ Email: marwansyah@polban.ac.id, trisetyowati@yahoo.com, \\ nurlailafadjarwati@yahoo.com, tia.fahmi@polban.ac.id
}

\begin{abstract}
Abstrak
Kegiatan ini bertujuan menata sistem penggajian untuk mewujudkan gaji yang adil dan layak bagi karyawan KWP. Luaran utama program ini adalah pedoman penggajian KWP yang memuat struktur dan tarif penggajian. Langkah-langkah penyusunan pedoman meliputi (a) survei pendahuluan, (b) benchmarking, (c) kajian atas sistem penggajian saat ini, (d) analisis jabatan, (e) evaluasi jabatan, (f) penyusunan struktur dan tarif gaji, dan (g) penyusunan pedoman penggajian. Evaluasi jabatan menggunakan metode point system, dengan lima faktor jabatan, yakni (1) tanggung jawab, (2) keterampilan, (3) upaya, (4) kondisi kerja, dan (5) risiko kerja. Metode ini dipilih karena bersifat kuantitatif dan relatif mudah digunakan serta dapat disesuaikan dengan perkembangan dan kondisi finansial KWP. Metoda point system menghasilkan besaran point untuk setiap jabatan di KWP (manajer, koordinator unit, staf dan operator). Point ini dikalikan dengan nilai rupiah tertentu untuk menghasilkan gaji pokok untuk setiap jabatan. Selain gaji pokok, ke dalam struktur gaji yang diusulkan, dimasukkan unsur-unsur imbalan lainnya, yakni (1) tunjangan isteri/suami dan (2) tunjangan anak. Selain itu, ke dalam perhitungan gaji dimasukkan unsur masa kerja.
\end{abstract}

Kata kunci: Gaji, sistem penggajian, analisis jabatan, evaluasi jabatan, Point System

\section{PENDAHULUAN}

Manajemen sumber daya manusia dapat diartikan sebagai pendayagunaan sumber daya manusia di dalam organisasi, yang dilakukan melalui fungsi-fungsi perencanaan sumber daya manusia, rekrutmen dan seleksi, pengembangan sumber daya manusia, perencanaan dan pengembangan karir, pemberian kompensasi dan kesejahteraan, keselamatan dan kesehatan kerja, dan hubungan industrial (Marwansyah, 2019). Perencanaan dan implementasi fungsi-fungsi ini harus didukung oleh analisis jabatan yang cermat dan penilaian kinerja yang obyektif (Marwansyah, 2019). Proses menemukan, mendayagunakan, mempertahankan, dan mengembangkan manusia dilakukan di setiap organisasi, termasuk lembaga koperasi. Salah satu fungsi penting dalam Manajemen SDM adalah pemberian imbalan/kompensasi atau penggajian. 
DIFUSI

Volume 2, No.2 Juli 2019

Gaji adalah imbalan yang diterima pekerja dari pengusaha untuk suatu pekerjaan atau jasa yang telah dilakukan, yang dinilai dalam bentuk uang yang ditetapkan menurut persetujuan atau peraturan perundang-undangan dan dibayarkan atas dasar perjanjian kerja antara pemberi kerja dan pekerja (Ruky, 2006). Prinsip pokok dalam pemberian gaji dan upah adalah adil dan layak (Marwansyah, 2019). Prinsip adil dapat dipenuhi bila organisasi memberikan imbalan secara proporsional berdasarkan kontribusi karyawan terhadap perusahaan. Kontribusi karyawan dinilai dengan menggunakan sejumlah faktor jabatan. Sementara itu, prinsip layak menunjukkan bahwa imbalan yang diberikan "sebanding" dengan imbalan yang diterima oleh karyawan dengan jabatan yang sama di organisasi sejenis. Kelayakan gaji dan upah juga dapat dilihat dari biaya hidup di tempat organisasi berada.

Sebagai sebuah badan usaha, Koperasi Warga Polban (KWP) perlu menegakkan prinsip adil dan layak dalam memberikan imbalan kepada para karyawan. Pengelolaan imbalan yang efektif menjadi salah satu kunci keberhasilan dalam menjalankan kegiatan usaha. Cara-cara lama yang cenderung tidak transparan dan tidak memiliki parameter obyektif dan terukur dalam pemberian gaji, harus ditinggalkan.

Target yang ingin dicapai adalah penataan sistem penggajian karyawan KWP, yang meliputi kajian dan perancangan struktur dan tarif gaji, untuk mewujudkan gaji yang adil dan layak. Luaran yang dihasilkan adalah pedoman penggajian sebagai metode untuk meningkatkan kualitas manajemen penggajian.
Keberadaan pedoman ini diharapkan dapat berkontribusi terhadap perbaikan tata kelola KWP sebagai badan usaha yang siap melangkah maju, kompetitif, dan semakin berkembang dalam memberikan layanan kepada para anggotanya. Pedoman ini telah disosialisasikan kepada karyawan di semua unit, para pengurus dan pengawas KWP.

\section{METODE PELAKSANAAN}

Penyusunan pedoman penggajian menggunakan dua metode utama, yakni analisis jabatan dan evaluasi jabatan. Analisis jabatan adalah proses sistematik untuk menentukan keterampilan, tugastugas, dan pengetahuan yang diperlukan untuk menjalankan pekerjaan dalam sebuah organisasi (Mondy \& Martocchio, 2016). Analisis jabatan menghasilkan dua jenis informasi: deskripsi jabatan dan spesifikasi jabatan. Analisis jabatan menyediakan informasi penting bagi evaluasi jabatan, yakni sebuah proses untuk menentukan nilai relatif sebuah jabatan dalam hubungannya dengan jabatan lain (Mondy \& Martocchio, 2016).

Dalam evaluasi jabatan, dilakukan pembandingan secara sistematik antara jabatan dan nilainya untuk mengembangkan struktur balas jasa atau gaji yang rasional (Nilasari, 2016). Evaluasi jabatan juga dilakukan untuk nenentukan jenjang atau tarif gaji yang tepat melalui identifikasi "nilai" sebuah jabatan (Hay Group, Inc., 2005). Selain kedua metode ini, kegiatan penyusunan pedoman dilengkapi dengan sejumlah langkah sebelum dan sesudah analisis dan evaluasi jabatan. 
DIFUSI

Volume 2, No.2 Juli 2019

Luaran kegiatan $\mathrm{PkM}$ ini adalah pedoman penggajian karyawan KWP yang memuat struktur dan tarif gaji. Luaran ini diperoleh sesudah langkah-langkah berikut ini dilaksanakan.

1. Survei pendahuluan untuk mendapatkan gambaran umum tentang isu penggajian di KWP secara $\mathrm{u}$ mum.

2. Benchmarking tentang sistem penggajian.

3. Kajian secara rinci atas sistem penggajian di KWP saat ini.

4. Analisis Jabatan, yakni identifikasi atas semua jabatan yang ada di KWP; proses ini menghasilkan deskripsi jabatan dan spesifikasi jabatan.

5. Evaluasi Jabatan, yakni penentuan nilai jabatan dibandingkan dengan jabatan lain. Evaluasi jabatan dilakukan dengan tahap-tahap sebagai berikut:
a. menentukan faktor-faktor ja- batan yang penting;
b. menentukan jenjang faktor-fak- tor jabatan;
c. mengalokasikan point untuk setiap faktor dan subfaktor ja- batan;
d. mengalokasikan point untuk jenjang faktor; dan
e. menyusun point manual.

6. Menyusun struktur dan tarif gaji untuk tiap jabatan.

7. Menyusun pedoman lengkap penggajian.

8. Melakukan sosialisasi pedoman penggajian.

\section{HASIL DAN PEMBAHASAN}

\section{Data Umum KWP}

Pengelolaan KWP dilakukan oleh tiga unsur pengelola, yakni Pengurus, Pengawas, dan Manajer (yang membawahi para koordinator unit). Pengurus terdiri atas Ketua, Wakil Ketua, Bendahara, Sekretaris dan Anggota. Saat ini, Manajer KWP membawahi empat koordinator, yakni Koordinator Unit Usaha Simpan Pinjam, Koordinator Unit Usaha Toko, Koordinator Unit Usaha Fotokopi/Percetakan, dan Koordinator Unit Usaha Perumahan (berstatus 'proyek'). Para Pengurus dan Pengawas dipilih oleh anggota KWP melalui Rapat Anggota Tahunan (RAT). Sementara itu, manajer dan staf pelaksana diangkat oleh Pengurus.

\section{Benchmarking}

Kegiatan lain yang dilakukan adalah studi banding (benchmarking) ke salah satu koperasi sejenis (koperasi karyawan perguruan tinggi). Data diperoleh melalui wawancara dengan Ketua Koperasi (Bapak Haryo Satriyo Tomo).

Di Koperasi ini, unsur-unsur yang mendapat gaji adalah (1) pengawas, (2) pengurus, (3) manajer, (4) karyawan tetap, dan (5) karyawan kontrak (kontrak dengan Koperasi atau kontrak dengan rekanan). Penggajian pengurus, pengawas, karyawan fungsional, dan manajer berbasis laporan, sehingga gaji bulanan yang diterima bisa penuh atau tidak penuh. Selain gaji, pengurus dan pengawas mendapat insentif rapat sebesar $\mathrm{Rp}$ 100.000,00 jika rapat dilakukan dengan pihak eksternal.

Sistem penggajian diterapkan secara terpusat oleh Manajemen Koperasi. Sejak 2010, dilakukan perubahan sistem 
DIFUSI

Volume 2, No.2 Juli 2019

pelaporan. Pelaporan kinerja yang semula dilakukan setiap bulan, diubah menjadi per hari. Jumlah gaji yang diterima berkisar antara $\mathrm{Rp}$ 2.300.000,00 s.d. Rp 4.200.000,00 per bulan.

Gaji yang diterima terdiri atas (a) gaji pokok, (b) insentif kehadiran, (c) insentif kinerja, dan (d) insentif lembur. Sementara itu, gaji pokok ditetapkan berdasarkan pendidikan dan masa kerja. Insentif kinerja dibayarkan berdasarkan penilaian manajer. Insentif kehadiran dibayarkan berdasarkan kehadiran. Insentif Lembur diperhitungkan secara total dalam satu bulan. Jumlah jam kerja 42 jam per minggu. Jumlah kehadiran dalam sebulan (termasuk keterlambatan dan jam lembur) dikurangi jumlah jam kerja wajib per bulan, dibagi dengan 4 jam dikalikan harga point (harga 1 point $=\operatorname{Rp~75.000,00).~}$

Dengan demikian, take home pay rutin yang diterima pegawai Koperasi terdiri atas gaji pokok dan insentif kehadiran yang memperhitungkan upah minimum. Pegawai Koperasi menerima 14 kali gaji per tahun, yang terdiri atas (a) 12 kali gaji bulanan, Januari s.d. Desember, (b) satu kali gaji (gaji pokok) yang dibayarkan sebagai THR (Tunjangan Hari Raya), dan (c) satu kali gaji (bulan Maret) atau dividen sebesar $10 \%$ dari jumlah SHU; komponen terakhir ini tidak diserahkan dalam bentuk uang, tetapi berupa dana rekreasi bersama.

Selain gaji dan insentif, pegawai Koperasi mendapat tunjangan atau benefit dalam bentuk:

a. Dana Pensiun (usia pensiun maksimum 60 tahun), yang dipotong dari gaji. Dana ini dikelola oleh BNI, dengan 3 opsi (a) Dana Pensiun secara keseluruhan dibayarkan sekaligus saat pensiun, (b) 50\% Dana Pensiun dibayarkan sekaligus saat pensiun, dan sisanya dibayarkan rutin per bulan sampai usia 85 tahun, dan (c) Dana Pensiun secara keseluruhan dibayarkan rutin tiap bulan sampai usia 85 tahun.

b. Asuransi rawat jalan sebesar Rp 1 juta per tahun.

c. Asuransi rawat inap.

\section{Penyusunan Pedoman Penggaji- an}

Setelah survei pendahuluan, dilakukan identifikasi atas semua jabatan yang ada di KWP. Dari tahap ini diperoleh uraian jabatan untuk setiap jabatan. Deskripsi jabatan yang diperoleh dari KWP kemudian divalidasi dan dilengkapi dengan spesifikasi jabatan.

Tahap berikutnya adalah menentukan faktor-faktor jabatan (critical job factors) yang dinilai penting dan relevan dengan jabatan-jabatan yang ada di KWP. Dari sejumlah faktor jabatan yang umum digunakan dalam Point System (Sistem Angka), Tim memilih lima faktor dan enam sub-faktor jabatan berikut ini.

a. Tanggung jawab, yang terdiri atas dua sub-faktor, yakni (a) tanggung jawab atas peralatan dan bahan; dan (b) tanggung jawab atas kebijakan dan kualitas barang/jasa.

b. Keterampilan, yang terdiri atas dua sub-faktor, yakni (a) pendidikan; dan (b) pelatihan. 
DIFUSI

Volume 2, No.2 Juli 2019

c. Upaya, yang terdiri atas dua subfaktor, yakni (a) upaya fisik; dan (b) upaya mental.

d. Kondisi kerja.

e. Risiko kerja.

Setelah ditentukan faktor-faktor jabatan yang penting, tingkatan untuk semua faktor ini perlu ditetapkan. Penetapan tingkat dilakukan untuk mengidentifikasikan tingkat kesulitan jabatan terendah hingga tertinggi. Mengingat tingkat tanggung jawab atau faktor-faktor lain berbeda-beda antar satu jabatan dan jabatan lainnya, Sistem Angka membuat beberapa tingkat/jenjang untuk setiap faktor jabatan. Tim memutuskan untuk menggunakan tiga tingkat untuk semua faktor jabatan (ditunjukkan dalam tabel 1). Tingkat ini membantu Tim (sebagai analis) untuk memberi imbalan bagi derajat tanggung jawab, keterampilan, upaya, kondisi kerja dan risiko kerja yang berbeda-beda.

Definisi faktor dan sub-faktor jabatan

a. Tanggung jawab.

1) Tanggung jawab atas peralatan dan bahan (termasuk sumber daya keuangan).

Faktor ini mengukur tanggung jawab atas sumber daya finansial (misalnya, kas, cek, bukti pembayaran, anggaran, pendapatan), dan aset fisik (misalnya, komputer, mesin fotokopi, mesin register, furnitur, barang persediaan, perlengkapan). Faktor ini mempertimbangkan karakteristik tanggung jawab yang diemban pemangku jabatan (misalnya, penggunaan, keamanan, pemeliharaan, penyusunan anggaran, pemesanan barang), frekuensi pelaksanaan tanggung jawab, nilai sumber daya, dan sejauh mana tanggung jawab ini dibagi dengan pihak lain.

Level 1: Secara personal, menjalankan tugas pemeliharaan atas peralatan dan sumber daya yang digunakan dalam proses kerja; secara teratur menangani atau memroses uang tunai dan cek; bertanggung jawab atas penggunaan peralatan secara aman selain peralatan yang mereka gunakan secara pribadi.

Level 2: Berwenang menandatangani pembayaran tunai dalam jumlah kecil; bertanggung jawab atas pembelian sejumlah aset fisik atau persediaan; memantau atau berkontribusi dalam perumusan anggaran unit kerja/layanan atau proposal keuangan; bertanggung jawab atas perbaikan dan pemeliharaan aset fisik.

Level 3: Pemegang anggaran untuk unit kerja/layanan; bertanggung jawab atas pengaturan anggaran untuk unit kerja/layanan; bertanggung jawab atas pengadaan atau pemeliharaan semua aset fisik atau persediaan untuk unit kerja/layanan; bertanggung jawab atas anggaran untuk sejumlah layanan; bertanggung jawab atas pengaturan anggaran untuk sejumlah layanan; bertanggung jawab atas aset fisik untuk sejumlah layanan.

2) Tanggung jawab atas kebijakan dan kualitas barang/jasa. 
DIFUSI

Volume 2, No.2 Juli 2019

Faktor ini mengukur tanggung jawab atas perumusan dan implementasi kebijakan KWP serta atas kualitas barang dan jasa yang disediakan bagi pelanggan. Faktor ini mempertimbangkan karakteristik tanggung jawab dan tingkat kontribusi pemegang jabatan terhadap proses pembuatan keputusan yang relevan, misalnya, memberikan rekomendasi kepada pembuat keputusan. Faktor ini juga mempertimbangkan sejauh mana kebijakan atau layanan yang diberikan terkait dengan fungsi dan unit kerja tertentu atau dengan organisasi KWP secara keseluruhan, dan sejauh mana tanggung jawab ini dibagi dengan pihak lain.

Level 1: Mengikuti kebijakan yang ditetapkan oleh orang lain dalam menjalankan tugasnya; tidak bertanggung jawab atas pengembangan layanan atau produk, namun mungkin diminta memberi masukan atas kebijakan, prosedur atau peluang pengembangan; atau mengusulkan perubahan atas praktik-praktik kerja atau prosedur tertentu untuk bidang kerjanya sendiri.

Level 2: Mengimplementasikan kebijakan untuk bidang kerja sendiri dan mengusulkan perubahan kebijakan atau layanan yang berdampak di luar wilayah aktivitas pekerjaan sendiri; atau bertanggung jawab atas implementasi kebijakan dan pengembangan layanan/produk untuk satu layanan atau lebih dari satu bidang kegiatan.
Level 3: Bertanggung jawab atas berbagai implementasi kebijakan dan perumusan kebijakan atau pengembangan layanan atau produk untuk KWP secara keseluruhan.

b. Keterampilan

1) Pendidikan

Level 1: Lulusan pendidikan menengah (SMU/SMK) paling rendah setara dengan jenjang 2 atau lulusan Diploma 1, paling rendah setara dengan jenjang 3 KKNI.

Level 2: Lulusan Diploma 2 paling rendah setara dengan jenjang 4 atau lulusan Diploma 3, paling rendah setara dengan jenjang 5 KKNI.

Level 3: Lulusan Diploma 4 atau Sarjana Terapan dan Sarjana, paling rendah setara dengan jenjang 6 KKNI.

2) Pelatihan (pelatihan, pengetahuan, pengalaman).

Faktor ini mengukur semua bentuk pengetahuan yang dimiliki, yang diperlukan untuk menjalankan tugas-tugas dan tanggung jawab jabatan secara memuaskan. Aspek ini mencakup pengetahuan teoritis dan praktis; pengetahuan teknis atau pengetahuan di bidang profesinya; dan pengetahuan tentang kebijakan, peraturan, praktikpraktik organisasi dan prosedur yang terkait dengan pekerjaan. Faktor ini memperhitungkan tingkat pengetahuan yang setara dengan pendidikan formal pada butir (a), tanpa harus mengikuti studi secara formal; dan pengalaman 
praktis yang diperlukan untuk menjalankan tugas-tugas dan tanggung jawab jabatan secara memuaskan.

Level 1: Memahami sejumlah kecil prosedur kerja rutin yang dapat diperoleh melalui periode orientasi singkat atau on-the-jobtraining; atau memahami serangkaian prosedur kerja rutin yang mungkin berada di luar area kerjanya saat ini, yang memerlukan pelatihan kerja dan masa orientasi dalam periode tertentu; tidak diperlukan pengalaman.

Level 2: Memahami berbagai prosedur dan praktik kerja, beberapa di antaranya tidak rutin, yang memerlukan pengetahuan teoritis tingkat dasar. Pengetahuan ini biasanya diperoleh melalui pelatihan formal atau pengalaman setara; atau memahami berbagai prosedur dan praktik kerja, yang sebagian besar bersifat non-rutin, memerlukan pengetahuan teoritis tingkat menengah. Pengetahuan ini biasanya diperoleh melalui pelatihan formal atau pengalaman yang setara.

Level 3: Memahami berbagai prosedur dan praktik kerja, yang memerlukan keahlian dalam spesialisasi atau disiplin ilmu tertentu, didukung oleh pengetahuan teoritis atau pengalaman praktis yang relevan; atau memiliki pengetahuan khusus/spesialis tentang berbagai prosedur dan praktik kerja yang didukung oleh pengetahuan teoritis atau pengalaman praktis yang relevan.

c. Upaya.

a. Upaya fisik.

Faktor ini mengukur upaya fisik yang dilakukan secara teratur atau rutin dalam pekerjaan. Upaya fisik ini meliputi: berdiri, berjalan, mengangkat beban, dan sebagainya, yang terkait dengan tugas seharihari. Pertimbangan juga diberikan kepada tugas-tugas yang memerlukan posisi fisik yang kurang nyaman atau yang menimbulkan keletihan karena melakukan gerakan secara berulang-ulang.

Level 1:

1) Kombinasi duduk, berdiri dan berjalan dengan upaya fisik yang rendah. Mungkin diperlukan pengerahan upaya fisik ringan untuk periode pendek, misalnya memindahkan barang atau peralatan ringan; atau

2) Tugas-tugas mensyaratkan posisi duduk atau berdiri pada posisi terbatas untuk periode yang lama; atau

3) Tugas-tugas mensyaratkan upaya fisik ringan dengan frekuensi tinggi (sering) untuk periode pendek dalam shift kerja; atau

4) Kadang-kadang diperlukan pengerahan upaya fisik ringan untuk sejumlah periode yang lama dalam shift kerja; atau

5) Kadang-kadang diperlukan pengerahan upaya fisik sedang/moderat untuk sejumlah periode yang pendek dalam shift kerja. 
Level 2:

1) Sering melakukan usaha fisik ringan dalam beberapa periode yang lama selama shift kerja; atau

2) Kadang-kadang melakukan usaha fisik sedang/moderat dalam beberapa periode yang lama selama shift kerja; atau

3) Sering melakukan usaha fisik sedang/moderat dalam beberapa periode yang pendek selama shift kerja.

Level 3:

1) Diperlukan upaya fisik ringan secara terus menerus; atau

2) Sering mengerahkan upaya fisik sedang/moderat dalam beberapa periode yang lama selama shift kerja; atau

3) Kadang-kadang perlu mengerahkan upaya fisik yang berat dalam beberapa periode waktu yang pendek selama shift kerja; atau

4) Diperlukan upaya fisik sedang/moderat secara terus menerus dalam beberapa periode yang pendek; atau

5) Sering diperlukan upaya fisik berat dalam beberapa periode yang pendek selama shift kerja; atau

6) Kadang-kadang diperlukan pengerahan upaya fisik berat dalam beberapa periode yang lama selama shift kerja.

b. Upaya mental.

Faktor ini mengukur karakteristik, tingkat, frekuensi dan durasi upaya mental yang diperlukan untuk menjalankan pekerjaan (misalnya: konsentrasi, merespons pola kerja yang tak terduga; interupsi dan kebutuhan untuk memenuhi tenggat waktu).

Level 1: Kesadaran umum dan perhatian sensorik/panca indera; perhatian yang bersifat umum/ normal; sesekali diperlukan konsentrasi, dengan pola kerja dapat diprediksi dan sedikit faktor pengalih perhatian.

Level 2:

1) Sering diperlukan konsentrasi, dengan pola kerja dapat diprediksi dan sedikit faktor pengalih perhatian; atau

2) Sesekali diperlukan konsentrasi, dengan pola kerja tidak dapat diprediksi; atau

3) Sering diperlukan konsentrasi, dengan pola kerja tidak dapat diprediksi; atau

4) Sesekali diperlukan konsentrasi terus menerus atau untuk jangka waktu lama.

Level 3:

1) Sering diperlukan konsentrasi yang terus menerus; atau

2) Sesekali diperlukan konsentrasi yang kuat/intens; atau

3) Sering diperlukan konsentrasi yang kuat/intens.

d. Kondisi kerja.

Faktor ini mengukur kondisi kerja yang terkait dengan pekerjaan. Kondisi kerja adalah kondisi yang terjadi/dialami secara terus menerus dan teratur sebagai bagian dari tugas sehari-hari (bukan kondisi atau situasi temporer atau yang kadang-kadang 
terjadi/dialami). Kondisi yang tidak menyenangkan meliputi antara lain: debu, kotoran, minyak/oli, tanah, bau menyengat, panas dan dingin, cuaca ekstrim, dan kebisingan.

Level 1:

Jarang terpapar kondisi kerja atau bahaya yang tidak menyenangkan.

Level 2:

1) Sesekali terpapar kondisi kerja atau bahaya yang tidak menyenangkan; atau

2) Sesekali menggunakan transportasi darat dalam situasi darurat; atau

3) Sering menggunakan transportasi darat; atau

4) Sering bekerja di luar ruangan.

Level 3:

1) Sering terpapar kondisi kerja yang tidak menyenangkan; atau

2) Sesekali atau sering terpapar kondisi kerja yang sangat tidak menyenangkan.

e. Risiko kerja.

Faktor ini mengukur risiko/bahaya yang terkait dengan tugas sehari-hari dalam suatu pekerjaan. Aspek ini mempertimbangkan risiko terjadinya kecelakaan atau penyakit dari pekerjaan yang dijalankan, meskipun sudah mengikuti persyaratan dan prosedur keselamatan kerja. Risiko atau bahaya yang dialami meliputi antara lain: menghadapi orang-orang atau nasabah/anggota koperasi dengan perilaku agresif/mengancam; peralatan atau mesin; zat atau bahan kimia; penyakit; kondisi yang tidak sehat; ketinggian.
Faktor ini juga mengukur risiko kesalahan dalam pencatatan atau transaksi keuangan, misalnya yang terkait dengan jumlah uang/kas yang kurang atau tak sesuai, jumlah pengeluaran/pembayaran dan penerimaan.

Level 1: Pekerjaan melibatkan sejumlah risiko terjadinya kecelakaan kecil atau penyakit ringan; atau terjadinya kesalahan pencatatan atau transaksi keuangan, misalnya yang terkait dengan jumlah uang/kas yang kurang/tak sesuai, jumlah pengeluaran/pembayaran dan penerimaan dalam jumlah kecil.

\section{Level 2:}

1) Pekerjaan melibatkan risiko cukup tinggi atas terjadinya kecelakaan atau penyakit ringan; atau risiko kecil atas terjadinya kecelakaan atau penyakit sedang/moderat; atau terjadinya kesalahan dalam pencatatan atau transaksi keuangan, misalnya yang terkait dengan jumlah uang/kas yang kurang/tak sesuai, jumlah pengeluaran/pembayaran dan penerimaan dalam jumlah sedang; atau

2) Pekerjaan melibatkan risiko cukup tinggi atas terjadinya kecelakaan atau penyakit sedang/moderat; atau risiko sedang atas terjadinya kecelakaan atau penyakit berat/serius; atau terjadinya kesalahan dalam pencatatan atau transaksi keuangan, misalnya yang terkait dengan jumlah uang/kas yang kurang/ tak sesuai, jumlah pengeluaran/pembayaran dan penerimaan dalam jumlah besar. 
DIFUSI

Volume 2, No.2 Juli 2019

Level 3:

1) Pekerjaan melibatkan risiko tinggi atas terjadinya kecelakaan atau penyakit serius/berat; atau risiko sedang atas terjadinya kecelakaan atau penyakit yang mengancam nyawa; atau terjadinya kesalahan dalam pencatatan atau transaksi keuangan, missalnya yang terkait dengan jumlah uang/kas yang kurang atau tak sesuai, jumlah pengeluaran atau pembayaran dan penerimaan dalam jumlah besar; atau

2) Pekerjaan melibatkan risiko tinggi atas terjadinya kecelakaan atau penyakit yang mengancam nyawa; atau terjadinya kesalahan dalam pencatatan atau transaksi keuangan, misalnya yang terkait dengan jumlah uang/kas yang kurang/tak sesuai, jumlah pengeluaran/pembayaran dan penerimaan dalam jumlah yang bisa menyebabkan kebangkrutan.

Tahap berikutnya adalah mengalokasikan point untuk setiap faktor dan subfaktor jabatan. Alokasi point untuk faktor jabatan dilakukan dengan mempertimbangkan tingkat kepentingan faktorfaktor bagi jabatan sesuai karakteristik KWP. Tim menilai bahwa faktor terpenting adalah "tanggung jawab" dan diberi alokasi 400 point. Berturut-turut sesudah "tanggung jawab" adalah "keterampilan" (200 point), "upaya" (200 point), "kondisi kerja" (100 point) dan "risiko kerja" (100 point). Langkah berikutnya adalah mengalokasikan point ke dalam sub-faktor, dengan menggunakan pertimbangan yang sama ketika mengalokasikan point untuk faktor jabatan.
Dengan meletakkan faktor-faktor di satu sisi dan jenjang faktor di sisi lain, akan didapatkan sebuah matriks Sistem Angka (lihat tabel 1). Dimulai dari tingkat III, Tim (sebagai analis) secara subyektif mengalokasikan point maksimum yang dimungkinkan untuk tiap sub-faktor. Berikutnya, Tim mengalokasikan point untuk jenjang faktor. Begitu jumlah point maksimum untuk setiap faktor jabatan telah dialokasikan di bawah tingkat III, Tim mengalokasikan point pada setiap baris untuk menggambarkan tingkat kepentingan dari jenjang yang berbeda. Untuk memudahkan, biasanya interval point antar-jenjang dibuat sama, seperti yang diberikan untuk "tanggung jawab" dalam tabel 1 (interval 50).

Setelah didapatkan Matriks Point dan faktor-faktor jabatan (lihat tabel 1), matriks utama ini selanjutnya digunakan sebagai pedoman untuk menentukan nilai seluruh jabatan yang ada. Jika matriks point telah selesai dibuat, nilai relatif setiap jabatan dapat ditentukan. Proses ini bersifat subyektif. Tim harus membandingkan deskripsi jabatan dengan deskripsi untuk setiap sub-faktor. Penentuan nilai ditentukan dengan mempertimbangkan seluruh faktor jabatan dan tingkat yang sesuai dengan deskripsi dan spesifikasi masing-masing jabatan. Misalnya, untuk jabatan manajer, "tanggung jawab atas kualitas barang/jasa" dinilai pada tingkat tertinggi (tingkat III) sehingga diberi point " 250 " sementara kasir dinilai paling rendah tingkatnya pada faktor jabatan ini sehingga diberi point " 150 ." Setelah seluruh jabatan dinilai dengan mengaplikasikan matriks point, maka diperoleh 
DIFUSI

Volume 2, No.2 Juli 2019

jumlah point untuk semua jabatan (lihat tabel 2).

Kesesuaian deskripsi jabatan di KWP dengan deskripsi faktor dan sub-faktor dalam Sistem Angka yang sudah dibuat, mengungkapkan jenjang dan point untuk tiap sub-faktor dari setiap jabatan. Point tiap sub-faktor dijumlahkan untuk memperoleh jumlah point untuk satu jabatan. Setelah jumlah point untuk tiap jabatan diketahui, jabatan-jabatan itu disusun peringkatnya. Sebagai langkah akhir, Tim mengkaji kembali peringkat relatif ini untuk memastikan ketepatannya.

Dari aplikasi matriks point dalam tabel 2 , diperoleh peringkat jabatan berda- sarkan point yang ditunjukkan dalam tabel 3 .

Untuk mengonversi point setiap jabatan (lihat Tabel 3) yang diperoleh dari aplikasi matriks point dalam tabel 2 ke dalam rupiah, Manajemen KWP sebagai pengguna pedoman dapat menetapkan jumlah rupiah untuk tiap point. Penetapan jumlah rupiah ini dilakukan dengan mempertimbangkan kemampu-an KWP dalam membayar (ability to pay) dalam tahun berjalan. Sebagai contoh, bila setiap point diberi nilai $\mathrm{Rp} 5.000,00$, maka besaran gaji pokok untuk setiap jabatan dengan asumsi masa kerja 0 tahun ditunjukkan dalam Tabel 4.

Tabel 1. Matriks Point \& Faktor Jabatan

\begin{tabular}{|c|c|c|c|c|}
\hline \multirow{3}{*}{ No } & \multirow{3}{*}{ Faktor-Faktor Kritis } & \multicolumn{3}{|c|}{ Tingkat } \\
\hline & & Rendah & Moderat & Tinggi \\
\hline & & $\mathbf{I}$ & II & III \\
\hline \multirow[t]{3}{*}{1} & Tanggung Jawab & & & \\
\hline & a. Peralatan \& bahan & 50 & 100 & 150 \\
\hline & b. Kebijakan \& kualitas barang/jasa & 150 & 200 & 250 \\
\hline \multirow[t]{3}{*}{2} & Keterampilan & & & \\
\hline & a. Pendidikan & 40 & 70 & 100 \\
\hline & b. Pelatihan & 40 & 70 & 100 \\
\hline \multirow[t]{3}{*}{3} & Upaya & & & \\
\hline & a. Fisik & 25 & 50 & 75 \\
\hline & b. Mental & 75 & 100 & 125 \\
\hline 4 & Kondisi Kerja & 50 & 75 & 100 \\
\hline \multirow[t]{2}{*}{5} & Risiko Kerja & 50 & 75 & 100 \\
\hline & & & Jumlah Poil & 1000 \\
\hline
\end{tabular}


DIFUSI

Volume 2, No.2 Juli 2019

Tabel 2. Aplikasi Matriks Point

\begin{tabular}{|c|c|c|c|c|c|c|c|c|}
\hline \multirow[b]{2}{*}{ No. } & \multirow[b]{2}{*}{ Faktor-Faktor Kritis } & \multicolumn{7}{|c|}{ Jabatan } \\
\hline & & Manajer & $\begin{array}{r}\text { Staf } \\
\text { Akun. }\end{array}$ & $\begin{array}{c}\text { Cust. } \\
\text { Services }\end{array}$ & Teller & $\begin{array}{c}\text { Koord. } \\
\text { Unit } \\
\text { Usaha }\end{array}$ & $\begin{array}{r}\text { Staf } \\
\text { Adm. }\end{array}$ & Kasir \\
\hline \multirow[t]{3}{*}{1} & Tanggung Jawab & & & & & & & \\
\hline & a. Peralatan \& bahan & 150 & 100 & 50 & 50 & 100 & 50 & 100 \\
\hline & b. Kualitas barang/jasa & 250 & 250 & 250 & 250 & 250 & 150 & 200 \\
\hline \multirow[t]{3}{*}{2} & Keterampilan & & & & & & & \\
\hline & a. Pendidikan & 100 & 70 & 70 & 70 & 70 & 40 & 40 \\
\hline & b. Pelatihan & 100 & 40 & 100 & 70 & 70 & 40 & 40 \\
\hline \multirow[t]{3}{*}{3} & Upaya & & & & & & & \\
\hline & a. Fisik & 25 & 50 & 50 & 50 & 50 & 50 & 75 \\
\hline & b. Mental & 125 & 125 & 100 & 100 & 100 & 75 & 100 \\
\hline 4 & Kondisi Kerja & 50 & 75 & 75 & 50 & 75 & 50 & 100 \\
\hline \multirow[t]{2}{*}{5} & Risiko Kerja & 100 & 75 & 75 & 100 & 75 & 50 & 100 \\
\hline & Jumlah Point & 900 & 785 & 770 & 740 & 790 & 530 & 755 \\
\hline
\end{tabular}

Tabel 3. Peringkat Jabatan

Berdasarkan Point

\begin{tabular}{clc}
\hline Peringkat & Nama Jabatan & Jumlah Point \\
\hline 1 & Manajer & 900 \\
\hline 2 & Koord. Unit Usaha & 790 \\
\hline 3 & Staf Akuntansi & 785 \\
\hline 4 & Staf Cust. Services & 770 \\
\hline 5 & Kasir & 755 \\
\hline 6 & Teller & 740 \\
\hline 7 & Staf Adm/Operator & 530
\end{tabular}

Tabel 4. Besaran Gaji Pokok (masa kerja 0 tahun)

Nilai 1 point $=\operatorname{Rp} 5.000,00$

\begin{tabular}{|c|c|c|c|}
\hline $\begin{array}{c}\text { Pering- } \\
\text { kat }\end{array}$ & $\begin{array}{c}\text { Nama } \\
\text { Jabatan }\end{array}$ & $\begin{array}{c}\text { Jumlah } \\
\text { Point }\end{array}$ & Gaji Pokok \\
\hline 1 & Manajer & 900 & $4.500 .000,00$ \\
\hline 2 & $\begin{array}{l}\text { Koordinator } \\
\text { Unit Usaha }\end{array}$ & 790 & $3.950 .000,00$ \\
\hline 3 & $\begin{array}{l}\text { Staf } \\
\text { Akuntansi }\end{array}$ & 785 & $3.925 .000,00$ \\
\hline 4 & $\begin{array}{l}\text { Staf Cust. } \\
\text { Services }\end{array}$ & 770 & $3.850 .000,00$ \\
\hline 5 & Kasir & 755 & $3.775 .000,00$ \\
\hline 6 & Teller & 740 & $3.700 .000,00$ \\
\hline 7 & Staf Admin/ & 530 & $2.650 .000,00$ \\
\hline
\end{tabular}

Dari tabel 4, dapat disusun gaji pokok setiap pemegang jabatan dengan memperhitungkan masa kerja. Tarif kenaikan gaji pokok berdasarkan masa kerja yang diusulkan oleh Tim adalah 2\% setiap dua tahun. Selain gaji pokok, ke dalam struktur gaji yang diusulkan, dimasukkan unsur-unsur imbalan lainnya, yakni (1) tunjangan isteri/suami (10\% dari gaji pokok) dan (2) tunjangan anak (masingmasing $2 \%$ dari gaji pokok, untuk maksimal dua anak). Berdasarkan pedoman ini, disusun simulasi besaran gaji pokok + tunjangan untuk "manajer" dengan masa kerja 16 tahun, dengan satu isteri dan dua anak (lihat tabel 5).

Untuk menetapkan gaji pokok + tunjangan bagi semua pemangku jabatan, dilakukan proses yang sama dengan menggunakan pedoman yang sudah dibuat. Perlu ditegaskan bahwa pedoman ini hanya meliputi gaji pokok sesuai 
DIFUSI

Volume 2, No.2 Juli 2019

masa kerja ditambah tunjangan keluarga. Pemberian unsur-unsur imbalan lainnya, misalnya tunjangan atau insentif kinerja atau fasilitas tambahan seperti asuransi, di luar ruang lingkup pedoman ini.

Tabel 5. Simulasi Gaji Untuk "Manajer" Masa Kerja 16 Tahun (dalam rupiah)

\begin{tabular}{rlr}
\hline No. & Unsur Gaji & \multicolumn{1}{c}{ Tarif } \\
\hline 1. & Gaji Pokok Masa Kerja & \\
& 16 Tahun & $5,272,467.00$ \\
\hline 2. & $\begin{array}{l}\text { Tunjangan Isteri (10\% } \\
\text { X GP) }\end{array}$ & $527,246.72$ \\
\hline 3. & $\begin{array}{l}\text { Tunjangan Anak (2 X } \\
\text { 2\% X GP) }\end{array}$ & $210,898.69$ \\
\hline & Jumlah Gaji & $6,010,612.62$ \\
\hline
\end{tabular}

\section{KESIMPULAN}

1. Penggajian karyawan KWP yang memenuhi kriteria adil dan layak dilakukan melalui evaluasi jabatan dengan metode kuantitatif.

2. Sesuai karakteristik KWP, metode evaluasi jabatan yang digunakan adalah metode Point System (Sistem Angka).

3. Faktor jabatan yang digunakan dalam penggajian di KWP adalah tanggung jawab, keterampilan, upaya, kondisi kerja dan risiko kerja.

4. Komponen yang perlu ditambahkan ke dalam gaji pokok yang dibayarkan adalah tunjangan keluarga dan perhitungan masa kerja setiap dua tahun.

5. Penentuan nilai rupiah untuk setiap point dalam matriks point perlu mempertimbangkan kemampuan membayar KWP. (executive) maupun Badan Permusyawaratan Desa (legislative) sebagai pembentuk peraturan desa meningkat.

\section{SARAN}

1. KWP sebaiknya melakukan kajian ulang secara berkala terhadap besaran gaji yang dibayarkan (missalnya dengan menyesuaikan besaran/nilai rupiah untuk tiap point). Ini perlu dilakukan mengingat kondisi ekonomi yang berubah (misalnya, inflasi). Dengan demikian, gaji yang diterima tetap memenuhi kriteria layak (berdasarkan living costs).

2. Di luar gaji pokok dan tunjangan keluarga serta masa kerja, KWP perlu mempertimbangkan unsur-unsur imbalan lain yang dikaitkan dengan kinerja, misalnya tunjangan kinerja, bonus tahunan berdasarkan produktivitas (SHU).

\section{UCAPAN TERIMAKASIH}

Kami ucapkan terima kasih kepada Kepala UPPM Polban dan seluruh staf serta Ketua Jurusan Administrasi Niaga yang telah memberikan kesempatan dan kepercayaan kepada kami. Terima kasih yang tulus juga kami sampaikan kepada Pengurus dan Karyawan Koperasi Warga Polban yang telah bersedia menjadi mitra dan bekerja sama secara penuh serta memberikan dukungan bagi kelancaran pelaksanaan program ini.

\section{REFERENSI}

[1] Hay Group, Inc. (2005). Hay job evaluation: Foundations and application. Philadelphia: Hay Group.

[2] Marwansyah. (2019). Manajemen sumber daya manusia. (Edisi Kedua). Cetakan ke-5. Bandung: Alfabeta. 
DIFUSI

Volume 2, No.2 Juli 2019

[3] Mondy, R. W., \& Martocchio. J. J. (2016). Human resource management. (14th Ed). Boston: Pearson.

[4] Nilasari, Senja. (2016). Panduan praktis menyusun sistem pengga jian \& benefit. Jakarta: Raih Asa Sukses (Penerbit Swadaya Grup).

[5] Ruky, Achmad. (2002). Manajemen penggajian \& pengupahan untuk karyawan perusahaan. Jakarta: Gramedia Pustaka Utama 